\title{
Identity and the concept of the West: the case of Brazil and India
}

\author{
Identidade e o conceito do Ocidente: o caso do Brasil e da Índia
}

OLIVER STUENKEL*

Rev. Bras. Polít. Int. 54 (1): 178-195 [2011]

\section{Introduction}

In an international system dominated by the United States but subject to significant shifts of power towards other, less established powers, it is natural that there are growing efforts to analyze, understand and group these rising actors. ${ }^{1}$ The countless categories established over the past decade—ranging from the "Big Ten" ${ }^{2}$, G2 3 , G3, E-7, G20, L20, P21, ${ }^{4}$ BRICS, BRICSAM, BASIC, "Second World"5, "Pivotal States", and "Post-American World"6—are proof of this, yet all the attempts show how difficult it is to divide up countries in a meaningful way that enhances our understanding of the world.

The BRIC label has arguably been one of the most popular attempts to shape the way we understand rising non-established powers. Yet the major flaw of the grouping is that Russia and China stand apart from Brazil and India in the sense that they are well-established from an institutional point of view. Both are nuclear weapon states recognized in under the Non-Proliferation Treaty (NPT) and permanent UN Security Council members with veto power since 1945.7

\footnotetext{
* Visiting Professor of International Relations at the University of São Paulo (USP) and a Fellow at the Global Public Policy Institute (GPPi) in Berlin, Germany (oliver.stuenkel@post.harvard.edu).

1 Hurrell, Andrew (2006). Hegemony, liberalism and global power: what space for would-be great powers?, International Affairs, Vol. 82, No. 1. January 24, 2006.

2 Garten, Jeffrey E. (1997). The Big Ten: The Big Emerging Markets and How They Will Change Our Lives. New York: Basic Books, 1997.

3 Walker, Martin (2006). India’s Path to Greatness. The Wilson Quarterly (1976-), Vol. 30, No. 3 (Summer, 2006), pp. 22-30, 2006.

4 Cooper, Andrew F. and John English (2005). Introduction: Reforming the international system from the top: a Leaders' 20 Summit. In: English, John, Ramesh Thakur, Andrew F. Cooper (eds.) Reforming from the top: A Leaders' 20 Summit. Tokyo: United Nations University Press, 2005.

5 Khanna, Parag (2008). The Second World: Empires and Influence in the new global order, 2008.

6 Mahbubani, Kishore (2008). The New Asian Hemisphere: The Irresistible Shift of Global Power to the East, 2008. Zakaria, Fareed. The Post-American World, 2008.

7 One of the major disagreements during BRIC summits was Russia's and China's refusal to support India's and Brazil's quest for a permanent seat on the UNSC. It is precisely this episode that exemplified the major difference between Russia and China on the one hand, and Brazil and India on the other.
} 
Institutionally, they have been established poles of power since then. ${ }^{8}$ Brazil and India, on the other hand, are less recognized, "second-tier" actors that are neither fully part of the West nor squarely opposed to the current global order. While scholars have traditionally focused on great powers in international politics ${ }^{9}$, John Ciorciari notes that as rising non-established players such as India approach great power status, their strategic choices could have game-changing effects on the international system. ${ }^{10}$ It is these "undecided" countries, such as Brazil and India, on the fringe of the Western World Order that will, to an important degree, determine whether today's institutions will survive fundamental power shifts between nations or not. ${ }^{11}$

Yet defining Brazil's and India's identity is not an easy task precisely because both countries have been traditionally careful not to align too much with any blocs, and their positions in the world are in flux due to their rapidly increasing economic weight. Reflecting their institutional fringe status, it seems that their search for identity is intimately tied to the concept of the West. This study therefore aims to provide insights about how Brazil and India view and relate to the concept of the West, and how this affects their identity. Both countries' notions about the West are the subject of lively domestic discussion both in academia and the media, reflecting the struggle these countries find themselves in to define their identity as they rise. I argue that the concept of the West serves, in both Brazil and India, as a crucial concept to articulate their own identity — by a complex combination of criticizing, distancing itself from, or attempting to emulate the West. Virtually all attempts to articulate an identity stand in some relation to the West-an "independent" foreign policy, for example, implies the desire to act independently from the West and the necessity to keep the West at a distance. ${ }^{12}$ This shows that ownership of the West is not limited to the so-called Western countries. Western countries spend time seeking to define that the West is, but they have no monopoly to define what the West is. Concepts and words do not belong only to those described. It equally belongs to the people that use the concepts and words. Brazil and India, while not being fully part of the West, thus assume some ownership in the concept by applying it for their own needs, and play an important role in defining what the

8 Jackson, Robert and Georg Sørensen (2010). Introduction to International Relations. Oxford: Oxford University Press, 2010. In 1989, Henry Kissinger considered that the five great powers were the U.S., the Soviet Union, Japan, Europe and China. (Joseph Nye. Bound to lead: The Changing Nature of American Power, New York: Basic Books).

9 Waltz, Kenneth (1979). Theory of International Politics (New York: McGraw Hill), 1979.

10 Corciari, John D. (2009). What kind of power will India be? Indo-U.S. alignment and India’s Broader Foreign Policy Orientation. Panel on "Rising Powers", ISA New York, 2009.

11 Profound rearrangements of the global order have taken place historically via post-conflict settlements and orchestrating a rearrangement in times of peace will prove immensely complex, as power shifts usually lead to conflict. [Ikenberry, G. John (2001). After Victory: Institutions, Strategic Restraint, and the Rebuilding of Order after Major Wars. Princeton, NJ: Princeton University Press, 2001].

12 Hirst, Mônica (2005). The United States and Brazil: A Long Road of Unmet Expectations. New York: Routledge, 2005. 
West means. Brazil's and India's way of dealing with the concept of the West thus helps our understanding of both their identity, and of the West itself.

Gaining a better understanding of Brazil's and India's identity will also allow us to put both countries' foreign policy into context. India's economic and military might, for example, is increasing - yet India is neither a member of the UN Security Council nor of the G8, nor has it signed the NPT or joined a major military alliance system such as NATO. In the same way, Brazil is not a permanent member of the UN Security Council, is reluctant to join the OECD ${ }^{13}$, and has violated the NPT since 2004. ${ }^{14}$ Furthermore, Brazil and India are among the WTO members who most frequently issue complaints at the WTO. ${ }^{15}$ Finally, neither Brazil nor India is keen to embrace Western notions of liberal internationalism such as conditionality on development aid and the "responsibility to protect."

There is evidence of both countries' growing strategic assertiveness and self-confidence in pursuing an "activist foreign policy" 16 beyond their respective regions. ${ }^{17}$ In both societies, there is a predominant assumption that their nation has a destiny that has yet to be fulfilled, which has, inevitably, had a strong influence on foreign policy strategy. ${ }^{18}$ In 2005, Celso Amorim, Brazil's foreign minister, expressed the desire to "increase, if only by a margin, the degree of multipolarity in the world." 19 Both countries are invested in altering the international system. At the same time, they have a strong interest in rising within and engaging with the established structures. Gregory and de Almeida argue that there is a conception in Brazil's government that "supposes a fixed 'peripheral' status for Brazil." ${ }^{20}$ Precisely through their unwillingness to position themselves either as fully integrated or completely detached from the Western World Order, Brazil and India implicitly affirm their unique status and identity that requires further investigation. ${ }^{21}$

This article consists of three parts. Part one will give an overview over different ways to define the West, which helps us understand the different options Brazilian

13 Barbosa, Rubens (2005). O Brasil e a OECD. Estado de São Paulo. December 27, 2005; <http://www. eagora.org.br/arquivo/O-Brasil-e-a-OCDE/>.

14 Palmer, Liz and Gary Milhollin (2004). Brazil's Nuclear Puzzle. Science, New Series, Vol. 306, No. 5696, Gene Expression: Genes in Action (Oct. 22, 2004), p. 617.

15 Narlikar, Amrita (2006). Peculiar Chauvinism or Strategic Calculation: Explaining the Negotiation Strategy of a Rising India, International Affairs, Vol. 82, No. 1, January 2006, pp. 77-94.

16 Zakaria, Fareed (2008). The Post-American World, 2008.

17 Ganguly, Sumit (2006). Will Kashmir Stop India’s Rise? Foreign Affairs, July/August 2006.

18 New Directions in Brazilian Foreign Relations, Brazil Institute, Woodrow Wilson International Center for Scholars, September 28, 2007.

19 Hurrell, Andrew (2008). Lula’s Brazil: a rising power, but going where? Current History, 2008.

20 Gregory, Denise, and Paulo Roberto de Almeida (2008). Brazil and the G8 Heiligendamm Process. In Cooper, Andrew F. and Agata Antkiewicz (2008). Emerging Powers in Global Governance: Lessons from the Heiligendamm Process, Waterloo: Wilfrid Laurier University Press, 2008.

21 Raja Mohan, an Indian scholar, argues that India is in fact part of the West, while Western scholars such as Andrew Hurrell place it on the fringes of the Greater West [Mohan, Raja C. (2004). Crossing the Rubicon: The Shaping of India’s new Foreign Policy, 2004 and Hurrell, Andrew (2006)]. 
and Indian policy makers have to use the concept. Part two analyzes how Brazil and India define the West, how the West is used as a concept to define their own country, and how this relates to both countries' identity, and, ultimately, to their foreign policy. As a brief case example, this article will consider Brazil's and India's behavior in the UN General Assembly. Part three concludes.

\section{What is the West?}

While used frequently in the media, politics and academia ${ }^{22}$, the concept of the West remains abstract ${ }^{23}$ and poorly understood. ${ }^{24}$ In addition, it is not static, but in motion, continuously adapting to new realities, and imagined in new ways by different groups with different interests. Before we turn to Brazil's and India's vision of the West, it seems useful to understand in which ways scholars across the world have attempted to understand the West. While at times avoided by academics for its lack of specificity, the concept remains central. Several studies, such as those dealing with relations between Islam and the West show that the West can be used as a variable in serious academic studies. This is true not only in so-called "Western countries," but also outside. Chinese social scientist Sun Ge, for example, notes that

In the narratives of the Asian intellectuals, the West-an idealistic category with almost no significance to intellectuals of the West-is already there. Historically speaking, this idealistic category functions as the medium that pushes Asians into forming self-recognition. ${ }^{25}$

Yet how do we define the West? Which variables or proxies capture and represent the concept? In order to get a handle on what the West means, we shall consider the several dimensions through which the West is generally defined.

\section{Historical-religious dimension}

One of the most common dimensions used to define the West is the historical-religious dimension, which highlights the importance of Christianity. Historians identify Western Christianity as the precursor of the West. In the future, culture-shaping events such as the Reformation, the Counter-Reformation, and its intellectual legacy, would impact Western Christendom, but not Eastern Orthodoxy. Huntington argues that "Orthodox civilizations (...) inherited from

22 Bonnett, Alastair (2004). The Idea of the West: Culture, Politics and History. London: Palgrave Macmillan, 2004. 23 Akhavi, Shahrough (2003). Islam and the West in World History. Third World Quarterly, Vol. 24, No. 3 (Jun., 2003), pp. 545-562.

24 See, for example, Schlag, Gabi, Benjamin Herborth and Gunther Hellmann (2008). Secur(itiz)ing the West: The Transformation of Western Order. Conference Paper, 2008.

25 Sun, Ge (2000). How does Asia mean? (part II). Inter-Asia Cultural Studies, 1, 2, 2000 In: Bonnett, Alastair (2004). 
Classical civilization, but to nowhere near the same degree as the West." Ideas from Athens, Rome and Jerusalem are also said to have contributed to the formation of the West. Jeffrey Hart argues that the "Western being" defines itself through a common history, specifically Greek philosophy, cognition and science ("Athens") and spiritual aspiration to holiness ("Jerusalem"). ${ }^{26}$

Beyond Christianity, historians list historic events, ideas and trends—such as liberalism, social pluralism and rationality-as the defining characteristics of the West. Explaining what made the West Western, Samuel Huntington lists the emergence of several phenomena, dating back to pre-Socratic Greek philosophers, to less tangible and non-datable aspects, such as individualism. Huntington names the classical legacy (Greek philosophy and rationality, Roman law), Western Christianity (Catholicism and Protestantism), European languages, separation of spiritual and temporal authority, rule of law, social pluralism and civil society, representative bodies and individualism; but he also concedes that, individually, "almost none of these factors are unique to the West." 27

During the Cold War, the West temporarily took on another meaning and turned into a synonym of the "free," U.S.-led World, finding its counterpart in the Communist World led by the Soviet Union. ${ }^{28}$ After the Soviet Union's demise and the end of the Cold War, several analysts predicted, following a classic realist argument, that the Cold War was the primary source of Western solidarity ${ }^{29}$, and that the idea of the West would die as well. As Harries argued in 1993, "It took the presence of a life-threatening, overtly hostile 'East' to bring [the West] into existence and to maintain its unity. It is extremely doubtful whether it can now survive the disappearance of that enemy." ${ }^{30}$ Yet, the concept of the West continued to exist—both in the policy world ${ }^{31}$ and in academia — often in a similar form to its pre-Cold War definition. In the same year, Samuel Huntington published The Clash of Civilization and the New World Order, which used the concept of the West in a way that it did not need an Eastern counterpart. ${ }^{32}$ Since the terrorist attacks on September 11, 2001, the West is often understood in the context of the West vs. Islam debate.

26 Hart, Jeffrey (2001). Smiling through the Cultural Catastrophe: Toward the Revival of Higher Education. New Haven, NJ: Yale University Press, 2001.

27 Most scholars of civilization agree that Western civilization emerged in the $8^{\text {th }}$ and $9^{\text {th }}$ centuries and developed its distinctive characteristics in the centuries that followed. Huntington. Samuel P. (1996). The West Unique, Not Universal. Foreign Affairs, Vol. 75, No. 6 (Nov.-Dec., 1996), pp. 28-46.

28 Schlag, Gabi, Benjamin Herborth and Gunther Hellmann (2008).

29 Deudney, Daniel and G. John Ikenberry (1999). The Nature and Sources of Liberal International Order. Review of International Studies, Vol. 25, No. 2 (Apr., 1999), pp. 179-196.

30 Harries, Owen. The Collapse of 'The West'. Foreign Affairs, Vol. 72, No. 4 (Sep.-Oct., 1993), pp. 41-53. Deudney, Daniel and G. John Ikenberry (1993). The Logic of the West. World Policy Journal, Vol. 10, No. 4 (Winter, 1993/1994), pp. 17-25.

31 See, for example: Mahbubani, Kishore (1993). The Dangers of Decadence: What the Rest Can Teach the West. Foreign Affairs, 1993.

32 Huntington, Samuel (1993). Clash of Civilizations? Foreign Affairs, 1993. 
When we look at the idea of the West in its historical dimension, therefore, we can observe its persistency across vast quantities of historical time. On the one hand, the concept of the West has a strong solidity to it that stood the test of time. On the other hand, it shows how strategic and mobile definitions of the West have been across history. ${ }^{33}$ The idea that the West will end with the end of the Cold War ignores history.

\section{Cultural-values dimension}

Historians argue that the values usually seen as Western are those that emerged 500 B.C. in Ancient Greece until the present day: individualism, freedom, liberty, democracy, rationality, human rights, and capitalism. ${ }^{34}$ German historian Heinrich August Winkler describes the West as a "community of values," in which he includes Europe, the United States, Canada, New Zealand, Australia and, since 1948, Israel..$^{35}$ Gunther Hellman argues that the West is usually seen as a "culturally defined civilization with a clear and stable essence." ${ }^{36}$ Dean Acheson argued that the West can be defined by commonly held "moral and spiritual values." ${ }^{37}$

Yet, history is written by the victors - and Western nations have, militarily, clearly been on the winning side over the past centuries, most visible during the almost all-encompassing global Western dominance at the beginning of the $20^{\text {th }}$ century, and the creation of the "Western World Order" after World War II. Western history of the West (the story the West tells itself) is therefore likely to suffer from some degree of pro-Western bias. As Claude Lévi-Strauss points out, non-Western historical accounts of the West are rare, so we have only a limited capacity to assess the objectivity of the West's account of the West.

In addition, as Foucault points out, the self-definitions like the ones above by Heinrich August Winkler are rather to be understood as a kind of aspiration and normative concepts rather than an adequate description of the past. ${ }^{38}$ Since when are aspects such as individualism, liberty, democracy, rationality, human rights, and capitalism universally implemented concepts in Western societies? Individualism and rationality may have existed as concepts for a long time, but personal liberty remained restricted in many Western nations, such as the United States, until the civil rights movement in the 1960s, and several European countries, such as

\footnotetext{
33 Bonnett, Alastair (2004).
}

34 Huntington, Samuel (1996). The Clash of Civilizations and the Remaking of World Order. New York: Simon \& Schuster, 1996.

35 Winkler, Heinrich August (2010). Der Westen braucht den Streit. Final lecture, Humboldt University, February 14, 2007, <http://www.ksta.de/html/artikel/1171445238540.shtml>, accessed April 27, 2010.

36 Schlag, Gabi, Benjamin Herborth and Gunther Hellmann (2008).

37 Jackson, Patrick (2008). Defending the West: Occidentalism and the Formation of NATO. The Journal of Political Philosophy. 11,3, pp. 223-252, 2003. In: Schlag, Gabi, Benjamin Herborth and Gunther Hellmann (2008). 38 Foucault, Michel (1984), Paul Rabinow (ed.) The Foucault Reader. New York: Vintage Books, 1984. 
Portugal, did not grant women suffrage until the 1930s. Human or inalienable rights have been mentioned by thinkers across the ages, such as in Montesquieu's Spirit of the Laws in 1748 and the Virginia Bill of Rights in $1776 .{ }^{39}$ But their full-fledged application was, until recently, the exception rather than the norm. As Amartya Sen points out, similar concepts have been developed in the nonWestern world - such as during Akbar the Great's reign in what is today India (1542-1605). ${ }^{40}$ Capitalism was not introduced as an idea until 1776, and socialism and communism are as Western as capitalism. Alastair Bonnett points out that "the assumption that being Western means being law-governed and socially and technologically advanced is relatively recent." ${ }^{\prime \prime 1}$

This cultural-values lens has equally often been used by non-Western analysts, and they often ascribe specific negative values to the West. It became particularly popular in the 1990s, when so-called "Asian values," whose supporters attempted to differentiate them from "Western values," came into vogue, mostly to justify authoritarian regimes in Southeast Asia. Lee Kwan Yew, former Prime Minister of Singapore, and Kishore Mahbubani, a Singaporean writer, usually juxtapose Asian discipline, morality and order with Western chaos. As Lee Kwan Yew pointed out during an interview with Fareed Zakaria in 1994,

I find parts of [the West] totally unacceptable: guns, drugs, violent crime, vagrancy, unbecoming behavior in public-in sum the breakdown of civil society. The expansion of the right of the individual to behave or misbehave as he pleases has come at the expense of orderly society. In the East the main object is to have a well-ordered society so that everybody can have maximum enjoyment of his freedoms. This freedom can only exist in an ordered state and not in a natural state of contention and anarchy. ${ }^{42}$

In a similar vein, Kishore Mahbubani writes that

[In the West] "budgetary discipline is disappearing (...), work ethic is eroding (...) leadership is lacking (...). Any politician who states hard truths is immediately voted out (...). This is massive social decay. ${ }^{43}$

Indian thinkers, on the other hand, at times equate Western culture to rationality. Indian Hindu nationalists often contrast this with what they describe as an Indian culture of fatalism, passivity and excessive acceptance of life. George Tanham, an American scholar, argues that there is an "absence of strategic planning" in India

39 Winkler, Heinrich August (2010). Der Westen braucht den Streit. Final lecture, Humboldt University, February 14, 2007, <http://www.ksta.de/html/artikel/1171445238540.shtml>, accessed April 27, 2010.

40 Sen, Amartya (2006). Identity and Violence: The Illusion of Destiny. New York, W.W. Norton, 2006.

41 Bonnett, Alastair (2004).

42 Fareed Zakaria (1994). Culture Is Destiny: A Conversation with Lee Kuan Yew. Foreign Affairs, Vol. 73, No. 2 (Mar.-Apr., 1994), pp. 109-126.

43 Mahbubani, Kishore (1993). 
and blames "the Hindu concept of time, or rather the lack of a sense of time." $\mathrm{He}$ argues that "Indians view life as an eternal present, with neither history nor future." This, according to him, discourages planning, since "Hindus consider life a mystery, largely unknowable and not entirely under man's control. In this view, fate, intuition, and emotions play important roles, but how, how much and when is never known. Man's control over life is thus limited in Hindu eyes, and he cannot forecast or plan with any confidence." ${ }^{44}$ While these analysts clearly associate the West with rationalism, there is no consensus about this in India. Raja Mohan, for example, says that "India represents the triumph of the values of reason, cosmopolitanism, scientific progress and individual freedom." 45

Furthermore, critics of the West are not unified and struggle to establish non-Western ideas. "Non-Western" scholars have often attempted to establish "non-Western" ways of interpreting international relations, only to realize that the assumption that the "non-West" necessarily takes a view different from that of the "West" is highly problematic. After all, concepts such as the "Third World," the "Orient" and "Africa" are essentially Western inventions. The "non-West" is thus possibly just a Western idea, and many of the West's fiercest critics are Western themselves. Amartya Sen is opposed to developing "non-Western" ideas and argues that the West has been highly influenced by the "non-West," absorbing countless things Westerners deemed beneficial without worrying about importing "nonWestern" influence. Sen accuses those who seek to delineate the West of "praising an imagined insularity." $46 \mathrm{He}$ argues that to call ideas of liberal democracies and "democratic peace" Western is an example of this insularity. ${ }^{47}$

\section{Systemic-policy dimension}

Another commonly used way to define the West is by looking at a country's political system and government policies. During the Cold War, such thinking was particularly widespread..$^{48}$ The West was made up of liberal democracies, the rest was not. In addition, many policy analysts implied and still imply that specific foreign policy strategies, such as the promotion of democracy, free trade and the defense of human rights, are essentially Western. ${ }^{49}$

44 Tanham, George K. (1992). Indian Strategic Thought: An Interpretative Essay. Santa Monica, CA: Rand Corporation, 1992.

45 Mohan, C. Raja (2004).

46 Amartya Sen (2006). Identity and Violence: The Illusion of Destiny. New York, W.W. Norton, 2006. In: Bilgin, Pinar (2008). Thinking past 'Western' IR?, Third World Quarterly, Vol. 29, No. 1, 2008, pp. 5-23.

47 Amartya Sen (2006). Identity and Violence: The Illusion of Destiny. New York, W.W. Norton, 2006. In: Bilgin, Pinar. Thinking past 'Western' IR?, Third World Quarterly, Vol. 29, No. 1, 2008, pp. 5-23.

48 Analysts have sought to identify distinctions prior to the Cold War. For example, in The Prince, Machiavelli identifies strongly centralized governments with the East, and the looser confederate model with the West [Machiavelli, Nicolò (1992). The Prince. New York: Dover Publications, 2010].

49 Castañeda, Jorge G. (2010). Not Ready for Prime Time. Foreign Affairs, September/October 2010. 
In 1996, Huntington argues that "maintaining the unity of the West (...) is essential to slowing the decline of Western influence in world affairs." ${ }^{0}$ This implies that the West consists of countries that are aligned because they have the same goals, policies, or political systems. In 2006, for example, Kishore Mahbubani writes about "Western policies" in general, implying that the West is, in fact, a coherent political unity.

The attempt to define the West through its system of liberal democracy is difficult to sustain empirically. While many liberal democracies are Western, many other democratic states such as Colombia, South Africa and Ghana are not. In fact, of the world's five largest liberal democracies-India, the United States, Indonesia, Brazil and Japan-only one is within what we commonly call the West. Yet those who apply this definition rarely include such countries when talking about the West. In the same way, Turkey and Indonesia have stable democratic systems. The argument that Islam and democracy are incompatible is thus unconvincing. Democracy may be a concept that originated in the West, but it is difficult to claim that democracy in Brazil or India is less of a native concept than in a relatively young democracy like Germany or Portugal. Neither is it correct to argue that non-Western countries are democratic merely because Western countries implemented such a democratic system. The opposite is true. The British Empire granted no democratic rights to its colonies. They created ruling classes with highly concentrated power that made democratic governance less likely. Democratization in former colonies like Brazil occurred independently from Western influence. Contrary to what Kishore Mahbubani claims, democracy is not a uniquely Western value. ${ }^{51}$

The definition is equally difficult to sustain when looking at actual foreign policy strategy. The West may have some common civilizational background, but relationships between countries of the West have been marked by conflict and bloody internecine conflicts throughout most of its history, ${ }^{52}$ culminating in the "Western civil wars" of the $20^{\text {th }}$ century. ${ }^{53}$ The idea of common policies is relatively recent, but even now, aligned Western policies only occur if there is a common threat such as the Soviet Union. Free trade serves as a good example. Western nations may historically have supported free trade, but today there is little correlation between a nation's "Westernness" and its likelihood to support free trade-the world's two most open economies are Singapore and Hong Kong. ${ }^{54}$ This is not a

50 Huntington, Samuel P. (1996). The West: Unique, Not Universal. Foreign Affairs, Vol. 75, No. 6 (Nov.-Dec., 1996), pp. 28-46.

51 Mahbubani, Kishore (1993).

52 Harries, Owen (1993). The Collapse of 'The West'. Foreign Affairs, Vol. 72, No. 4 (Sep.-Oct., 1993), pp. 41-53.

53 Mahbubani, Kishore (1993).

54 According to the Economist Intelligence Unit (EIU), Singapore was the most open economy in 2010 (<http:// www.asiaone.com/Business/News/My+Money/Story/A1Story20100201-195831.html>, accessed May 2, 2010). Hong Kong was ranked second. 
recent phenomenon. In 1981, Mary Kaldor argued in "The Disintegrating West" that due to reduced competitiveness in comparison to Japan and Western Europe, it was no longer in the United States' national interest to promote free trade, creating "intra-West" conflicts. ${ }^{55}$ In the same way, there is no consensus among Western countries on fundamental aspects such as the death penalty, international law and global warming.

The three dimensions presented are all true to some degree, but rather than capturing the entirety of the concept of the West, they concur that there many different ways to interpret the West and to create a "Western narrative." In some dimensions it is a static monolith-like "Asia." In other dimensions it is very ephemeral-in terms of common policy. The West behaves very differently in its different dimensions. In addition, different groups define it differently according to their needs. Kemal Ataturk idealized the West partly because Westernization would help him defeat the remaining power structures from the Ottoman Empire. In the same way, $\mathrm{Al}$-Qaeda portraits the West as evil to create a potent image of a common enemy. Western politicians define the West in terms of values when trying to make the case for war against the Taliban in Afghanistan. The concept of the West is extremely elastic and so flexible that it even thrives on contradictory usage. Throughout history, for example, it was commonplace that the West was pronounced dead by some, while simultaneously regarded triumphant by others. In 1907, for example, Little foresaw the West's end in The Doom of Western Civilization, ${ }^{56}$ while Benjamin Kidd's Principles of Western Civilization praised the West in 1902, predicting its victory. ${ }^{57}$ The very same contradiction continued throughout the century, when Victor Hanson's Why the West has Won (2001) ${ }^{58}$ was matched by The Death of the West, written by Buchanan in 2003. ${ }^{59}$ While the Bolsheviks associated the West with socialist modernity, the West became a symbol of anti-communism during the Cold War. Its fluidity and malleability is likely to ensure its survival in the centuries to come.

\section{Identity and the concept of the West: the case of Brazil and India}

\section{Institutions as a proxy for the West}

How do Brazil and India see and define the West? How does this perception relate to their identity as emerging powers and affect their foreign policy? The

55 Kaldor, Mary (1978). The Disintegrating West. London: Allen Lane, 1978.

56 Little, J. (1907). The Doom of Western Civilization. London: W.H. and L. Collinbridge, 1907.

57 Kidd, Benjamin (1902). Principles of Western Civilisation: Being the First Volume of a System of Evolutionary Philosophy. London: Macmillan, 1902.

58 Hanson, V. (2001). Why the West has Won: Carnage and Culture from Salamis to Vietnam. London: Faber \& Faber, 2001.

59 Buchanan, P. (2003). The Death of the West: How Dying Populations and Immigrant Invasions Imperil Our Country and Civilization. New York: Thomas Dunne Books, 2003. In: Bonnett, Alastair (2004). 
short answer is that they regard and interpret the West as a key ingredient of their own identities, both positively ("we are part of the West" or "we are partly Western”), and negatively ("we are unlike the West", "we are non-Western”). Yet Brazil and India also define the West in its practical geopolitical consequences. Practically speaking, for Brazil and India, the West is not merely culture, history, policy, or values. Rather, the West's practical consequence is the international order - the so-called "Western World Order" — which, in turn, is made up of today's institutions. They interact with the West by interacting with the system. International institutions may thus serve as a proxy for the West.

By treating the Western World Order as a practical consequence of the West, Brazil and India address the question using William James's "pragmatic method," which is "primarily a method of settling metaphysical disputes that otherwise might be interminable." 60 James's theory allows us to respond to the question practically without finding an actual solution. The pragmatic method, James points out, is to try to interpret each notion by tracing its respective practical consequences. ${ }^{61}$ The Western World Order is the practical consequence of "the West."

For example, the European Union performs this gatekeeper function: the question of who is European and who is not has, with few exceptions, been reduced to the question of membership in the institution. Even though Europe as a concept has existed long before the EU, being a member country is a defining characteristic of being European. This may partly explain the fierce debate about Turkey's accession to the EU. The case of Russia is no different. As Dmitri Trenin points out, Russia "left the West" because the West "offered Russia no real prospect of membership in either NATO or the EU. The door to the West would officially remain open, but the idea of Russia actually entering through it remained unthinkable." 62

This example shows how strongly membership in some key international institutions captures the concept of the West. The G7's decision to include Russia was, after all, principally intended to tie Moscow to the West, underlining the weight of membership. In 1993, political commentator William Pfaff argued that "the West should act through NATO to guarantee existing borders in the Balkans and in Eastern Europe" 63 , showing that institutions are, in fact, a useful tool to capture what the West is. Similarly, Charles Kupchan reasoned in 1996 that the West could only be strengthened by broadening and deepening collaborative

60 James, William (1904). What is Pragmatism, from series of eight lectures dedicated to the memory of John Stuart Mill, A New Name for Some Old Ways of Thinking, in December 1904, from William James, Writings 1902-1920, The Library of America.

61 Mill, John Stuart (1904). A New Name for Some Old Ways of Thinking, in December 1904, from William James, Writings 1902-1920, The Library of America.

62 Trenin, Dmitri (2006). Russia Leaves the West. Foreign Affairs, Vol. 85, No. 4 (Jul.-Aug., 2006), pp. 87-96.

63 See, for example: Sjursen, Helene (2004). On the identity of NATO. International Affairs, 80, 4 (2004). Harries, Owen (1993). The Collapse of 'The West'. Foreign Affairs, Vol. 72, No. 4 (Sep.-Oct., 1993), pp. 41-53. 
institutions. ${ }^{64}$ U.S. efforts to reintegrate Germany into the West after WWII consisted largely of including the country into the Atlantic and Europe-wide institutions.

\section{The West, identity and ownership}

Brazilian and Indian diplomats' and scholars' characterizations about their countries are surprisingly heterogeneous, yet the concept of the West is often used to as a means of self-identification. Self-definitions in both countries range from "Western" to "partly Western" to "not Western." ${ }^{5}$ Even though many analysts describe their country's foreign policy as "multipolar" or "reformist" 66 or "independent," ${ }^{67}$ the West is often used as a reference point.

For decades, Brazil's relation to the West has been a mixture of attraction and aversion. Rubens Barbosa, a former diplomat, argued that Brazil should join the OECD, ${ }^{68}$ but joining the "club of the rich" that essentially symbolizes the West was rejected by the government for ideological reasons. ${ }^{69}$ Brazilian diplomats usually reject the claim that Brazil is generally "satisfied" with the current Western World Order.

India's status is slightly different, and Indian diplomats consistently categorized themselves as "less Western" than Brazil during the interviews, however not entirely "non-Western." The creation of the Non-Aligned Movement (NAM) in 1961, an intergovernmental organization of states considering themselves not formally aligned with or against any major power bloc, was an expression of how states that did not want to align or oppose the Western World Order sought to position themselves. ${ }^{70}$ In India's case, this turned out to be the singular feature of the country's policy since Independence in 1947. Nehru himself often had existential doubts about whether he belonged to the East of the West. ${ }^{71}$ In articulating India's views, it turned out to be much more aligned with the Soviet

64 Kupchan, Charles A. (1996). Reviving the West. Foreign Affairs, Vol. 75, No. 3 (May-Jun., 1996), pp. 92-104. 65 Interview, Brazilian Diplomat, Itamaraty, Brasilia, July 23, 2010, Interviews and phone interviews, Indian diplomats, New Delhi, March, April, May, June 2010.

66 Seitenfus, Ricardo (2006). O Brasil e suas relaçôes internacionais, Fernando Schüler e Gunter Axt (Orgs.), Brasil contemporâneo: crônicas de um país incógnito, Porto Alegre, Ed. Artes e Ofícios, 2006, pp. 129-150. 2 out. 2006.

67 Soares de Lima, Maria Regina (2003). Na trilha de uma política externa afirmativa. Observatório da Cidadania, 2003.

68 Barbosa, Rubens (2005). O Brasil e a OECD. Estado de São Paulo. 27 dez. 2005; <http://www.eagora.org. br/arquivo/O-Brasil-e-a-OCDE/>.

69 Sennes, Ricardo, Alexandre de Freitas Barbosa. Brazil's Multiple Forms of External Engagement: Foreign Policy Dilemmas (2005). In: Reforming from the Top: A Leader's G20 Summit. J. English, R. Thakur, A.F. Cooper (eds.), pp. 201-229. Tokyo: United Nations University, 2005.

70 The movement is largely the brainchild of India’s first Prime Minister Jawaharlal Nehru, president of Egypt Gamal Abdul Nasser and Yugoslav president Josip Broz Tito.

71 Varma, Pavan K. (2006). Being Indian: Inside the Real India. London: Arrow Book, 2006. 
Union than with the West. ${ }^{72}$ In 1976, a constitutional amendment was passed to make India a socialist republic. ${ }^{73}$

During interviews for this study, Indian interviewees have affirmations as diverse as "India is not part of the West" and "from a policy point of view (...) India is essentially part of the West."74 Raja Mohan, an influential Indian foreign policy thinker, sees India "returning to the West" after a misguided alignment with the Third World after Independence. Mohan laments that India was the only democracy that stood against the West during the Cold War on most issues, and former Foreign Minister Jaswant Singh described the history of India's bad relations with the United States as "fifty wasted years."75 Adopting the logic of Kant's democratic peace, Singh implied that, given that both countries were "Western-style" liberal democracies, they should have aligned long ago. Similar considerations have been made by Brazilians concerning U.S.-Brazil relations. Mônica Hirst describes these relations as a "long road of unmet expectations." "6

Unsurprisingly, then, scholars-like Indians and Brazilians themselves- have sought but struggled to find an adequate category for Brazil and India. The question of "Westernness" is always important; the challenge is to find some category that is more useful than "Western" or "non-Western" or "somewhat-non-Western but returning to Westernness." The apparent success of the BRIC label, a largely void term that merely groups four disparate emerging economies ${ }^{77}$ and which has often been characterized as essentially "anti-Western" in both the media and the academic world, shows the yearning for an adequate term. Terms like "second world," "swing states," "monster countries" and "anchor countries" have failed to win broad acceptance in today's discourse.

Ultimately Brazil's and India's frequent usage of the concept of the West shows that both countries have some ownership over the definition of the West. Not only "Western" self-definitions determine what the West means. All countries that use the concept play a major role in its definition. A fitting analogy is the discussion that arose in September 2010 from the plans to build a Muslim Community Center close to the site of the September 11, 2001 terrorist attacks. The ensuing domestic debate about the nature of American values implied that most Americans believed it rested on them to define what it meant to be American. Yet, in fact, the debate took place on a global scale, and the debate about what it meant to be American was not limited to U.S. citizens. While Americans participated in the debate, they

72 Cohen, Stephen P. (2000). India Rising. The Wilson Quarterly (1976-), Vol. 24, No. 3 (Summer, 2000), pp. 32-53.

73 Mohan, C. Raja (2004).

74 Interviews and phone interviews, Indian diplomats, New Delhi, March, April, May, June 2010.

75 Mohan, C. Raja (2004).

76 Hirst, Mônica (2005). The United States and Brazil: A Long Road of Unmet Expectations. New York: Routledge, 2005.

77 Hurrell, Andrew (2006). 
clearly did not have sole ownership of the process of defining what it means to be American. Defining "American-ness" is thus open to people across the world, and they will define it according to their own perspectives and needs. In the same way, the idea and the concept of "the West" does not belong solely to the West-but to everyone who uses it, however they choose to use it. The notable difference is, of course, that "America" is a clearly defined entity, while "the West" is, in both Brazil's and India's case, related to their self-definition.

\section{Brazil's and India's ambivalence about the West}

In the interviews conducted for this study, Brazilian and Indian academics show a heterogeneous understanding of the West, mixing ideological criticism with pragmatic affirmation. Rhetoric is often anti-Western and highly critical of international institutions such as the IMF, which is often ideologically regarded as a tool of Western dominance. Mohan points to a strong "anti-imperialist" tradition and to nativist ideologies which put India and the West at opposite poles. ${ }^{78}$ As Oliveira and Onuki point out, there is a widespread opinion among Brazilians that, given its position at the periphery, Brazil can only engage in "conformism, subordination, without space for courage." 79 And Samuel Pinheiro Guimarães, President Lula's chief foreign policy strategist, divides the world into sovereign states and subordinate ones, the center versus the periphery, and "contented" states versus "contesting," placing Brazil in the latter category of each juxtaposition. ${ }^{80}$ U.S.-friendly policies in the 1990s driven by "liberal fascination," only contributed to more subordination, according to Guimarães. Instead, Brazil should "challenge the giants." ${ }^{1}$ However, this opinion is by no means generally accepted, but frequently criticized as "third worldish" and "dogmatic," as a Brazilian diplomat called it. ${ }^{82}$ More pragmatic voices recognize that India's fundamental values and interests are broadly compatible with those of the West, pointing to its "deeply entrenched democratic heritage, its successful market economy and its open culture and English language." 83

At the same time, both Brazilian and Indian scholars have often attempted to counteract against the assumption of a "teleological Westernization" ("they all seek

78 Mohan, C. Raja (2004).

79 de Oliveira, Amâncio Jorge e Janina Onuki (2006). Resenha de "Uma visão altiva da periferia de Samuel Pinheiro Guimarães”, Revista Brasileira de Ciências Sociais, outubro, vol. 21, número 062, Associação de PósGraduação e Pesquisa em Ciências Sociais, São Paulo, pp. 154-157.

80 Guimarães, Samuel Pinheiro (2006). Brasil na Era dos Gigantes. Rio de Janeiro: Contraponto, 2006.

81 Ibid.

82 Telephone interview with a Brazilian diplomat based in Brasília, Brazil, July 1, 2010.

83 Babbage, Ross (2009). India's Strategic Development: Issues for the Western Powers. In India's Strategic Future, Babbage and Sandy Gordon (eds.), Houndmills, UK: Macmillan. In: Baldev Raj Nayar. India as a limited challenger? T.V. Pauli and John A. Hall (eds.) International Order and the Future of World Politics. Cambridge: Cambridge University Press, 1999. 
to become like us anyhow")—which caused them to find a way to somehow do things differently. Former undersecretary of defense Ashton Carter comments that Indian diplomats are "notorious for adhering to independent positions regarding world order." ${ }^{44}$ Pinar Bilgin describes fringe nation's strategy as "almost the same but not quite," suggesting that "'mimicry' may be a way of 'doing' world politics in a seemingly 'similar' yet unexpectedly 'different' way." ${ }^{85}$ When Brazilian and Indian scholars align with Western or American points of view, they at times apologetically argue that the spread of U.S. approaches can be explained by the emergence of the U.S. as the "dominant producer of both ideas and things," which coincided with and provided a basis for the modernization and/or Westernization projects of elites in various parts of the world. ${ }^{86}$

A certain ambivalence about Brazil's and India's position towards the West and the Western World Order is thus clearly visible. ${ }^{87}$ Engaging with the Western World Order has provided benefits, but also caused humiliation. The IMF's influence in the early 1990s was so palpable that one economist claimed that "while the rajputs and princely states had a fair degree of autonomy in relation to the British colonial government (...), under IMF-World Bank tutelage, the union minister of finance reports directly to $1818 \mathrm{H}$ Street NW, Washington, D.C., bypassing the parliament and the democratic process." 88 In a similar fashion, Joseph Stiglitz compared India's agreement to the IMF with the "surrender of Maharajas to the British." 89

The most dominant critique from leftist groups in both India and Brazil is that the Western World Order is no different from previous hegemonic systems and just another form of domination, in no way different from any other world order that has existed before, and that today's Western-centered order does not represent an extension of liberal democratic state structures. Nayar and Paul, for example, affirm that "The entire structure is of Western design and construction, preserves Western power, and serves Western interests." ${ }^{.90}$ In a similar vein, Chandra argues that the conventional Marxist theory of imperialism provides strong insight into the "workings of neocolonialism."

84 Carter, Ashton B (2006). America’s New Strategic Partner? Foreign Affairs, Vol. 85, No. 4 (Jul.-Aug., 2006), pp. 33-44.

85 Bilgin, Pinar (2008). Thinking past 'Western' IR?, Third World Quarterly, Vol. 29, No. 1, 2008, pp. 5-23. 86 Ibid.

87 Nayar, Baldev Raj (1999). International Order and the Future of World Politics. Cambridge: Cambridge University Press, 1999.

88 Chossudovsky, M. (1993): India under IMF Rule, Economic and Political Weekly, Vol. 22 Issue 6, March 6, 1993.

89 Stiglitz, Michael (1998). Globalization and its Discontents. New York: W.W. Norton \& Company, 1998.

90 Nayar, Baldev Raj and T.V. Paul (2003).

91 Chandra, Nirmal Kumar (1998). The Retarded Economies. Bombay: Oxford University Press, 1988. 
Many Brazilian and Indian critics of the West and of the Western World Order are also critics of globalization. Globalization is, according to this point of view, a tool of Western imperialism, principally aimed at promoting Western interests. A lot of anti-Western sentiment is therefore, implicitly, directed against globalization and modernization in general. These critics, often part of the so-called "anti-globalization movement," are right to point out that the Western World Order and globalization are closely intertwined concepts, and that several, if not all, of the institutions that make up the Western World Order contribute to the institutionalization of global rules and norms. Institutions such as the WTO are for many a symbol of globalization. International institutions are thus an important dimension of globalization.

At the same time, there is, in India and Brazil, a growing consciousness that accepting a multilateral order built on U.S. principles has allowed India to grow phenomenally. A Brazilian diplomat admitted that IMF intervention in Brazil was "crucial," but that this was "not a popular thing to say." 92 Despite their ambivalence about the Western World Order, and their uncertainty about whether they themselves are Western or not, the "fringe," consistent of countries such as Brazil and India, is probably the party that most explicitly equates the international institutions with the West-there is an ideological predisposition to criticize and refrain from integration, but a pragmatic necessity to join the system to continue to benefit from it and a desire to rise within it. Both countries are thus in critique of the West, but they also use the Western system to their advantage.

Brazil and India are thus partially integrated into the Western system (as liberal democracies and IMF lenders), but not enough as to represent a purely Western perspective. Amâncio Oliveira and Janina Onuki describe Brazil as "peripheral, but with potential to play an autonomous role in international politics." 93 India's leadership in the Non-Aligned Movement and Brazil's status as an observer indicate a certain distance to the Western-led world order. Brazil and India have aligned in many instances, but they also belonged at some point to the West's principal opponents.

\section{Conclusion}

As this paper has shown, the concept of the West plays a key role in both Brazil's and India's articulation of their identity. What is striking is that while the West serves as an important reference point that helps Brazilians and Indians define themselves (e.g. "partly Western"), they characterize this reference point in

92 Interview with a Brazilian diplomat, Brazilian Foreign Ministry, July 1, 2010.

93 de Oliveira, Amâncio Jorge e Janina Onuki (2006). Resenha de "Uma visão altiva da periferia de Samuel Pinheiro Guimarães”, Revista Brasileira de Ciências Sociais, outubro, vol. 21, número 062, Associação de PósGraduação e Pesquisa em Ciências Sociais, São Paulo, pp. 154-157. 
countless different ways, ranging from the West as the source of colonial imperialism to a notion that India needs to adopt more "Western values." The West is such a malleable concept that it is used frequently to serve their cause: to create an enemy (the imperial West), as a tool to identify oneself (we are "not Western," "Western" or "partly Western"), and as an ideal to push reforms ("Western standards"). The task of defining the West thus does not lie solely with the West itself. Those located on the "fringes" of the Western system are equally important participants in the process of defining what the West means. It seems quite natural that, in a world of diverse actors with differing sets of interests, there will be disagreement about what the West is. But despite that, there can be "communities" of actors who define the West in similar ways. Brazil and India are in the same community, principally because of their specific position on the fringes of the West. Both India and Brazil are expressing their ambiguous thought about the West by their ambiguity towards Western institutions.

Notions about the Western World Order (our current global order) are particularly interesting because Brazil's and India's weight is increasing. As a consequence, their interests are increasingly different from those of other nonWestern developing countries, and more like those of developed Western countries. This creates an interesting dilemma for these partly Western emerging powers which continue to strongly identify with their non-Western, underdeveloped side. Their economic rise and increased status in the international community is therefore likely to cause a conflict of identities. As Hurrell points out, a certain ambiguity remains about whether Brazil's and India's language of Third Worldism and southern solidarity is simply a rhetorical remnant of the past, interest-driven strategy, or a reflection of a deeper set of beliefs. If it is the latter, "what happens if the 'developing country identity' conflicts with the aspiring 'great power identity'?"94

Received February 6, 2011

Accepted April 7, 2011

\begin{abstract}
This study aims to provide insights about how Brazil and India view and relate to the concept of the West, and how this affects their identity and foreign policy. Both countries' notions about the West are the subject of lively domestic discussion both in academia and the media, reflecting the struggle these countries find themselves in to define their identity as they rise. I argue that the concept of the West serves, in both Brazil and India, as a crucial concept to articulate their own identity-by a complex combination of criticizing, distancing itself from, or attempting to emulate the West.
\end{abstract}

Keywords: identity; emerging powers; the West; Brazil; India.

94 Hurrell, Andrew (2006). 


\section{Resumo}

Este estudo visa a discorrer sobre como o Brasil e a Índia veem e se relacionam com o conceito do Ocidente, e como isso afeta sua identidade e política externa. As noções de ambos os países sobre o Ocidente são o tópico de cinco acaloradas discussões internas tanto na Academia quanto na mídia, refletindo a luta em que esses países se encontram para definir sua identidade à medida que emergem. Debate-se que o conceito do Ocidente serve, tanto no Brasil quanto na Índia, como um conceito crucial para articular sua própria identidade - por meio de uma combinação complexa de crítica, distanciamento, ou tentativa de emular o Ocidente.

Palavras-chave: identidade; potências emergentes; o Ocidente; Brasil; Índia. 